En esta sección compartimos las opiniones que nos envían nuestros lectores sobre los artículos publicados en el ejemplar del Cuaderno de Pedagogía Universitaria: No. 24 / julio - diciembre 2015

\section{Aspectos fundamentales que definen al maestro y su rol}

En este artículo se puede apreciar cómo el Lic. Wilfredo Rosario describe con mucha precisión y claridad la personalidad científica del maestro, resaltando la identidad individual, la relación con el mundo y, sobre todo, el deseo de conocer, motivado por la curiosidad natural y su empeño de erradicar la ignorancia.

Me parece muy acertado insistir en la necesidad de que el maestro muestre ese afán por conocer las cosas a través de la búsqueda continua y sistemática del saber.

Comparto la idea de que el maestro debe ser un agente investigador que genere ideas, que las aplique y que las vincule con su diseño pedagógico y estratégico anclado en verdades objetivas. De hecho, para que una docencia sea eficaz, los maestros debemos utilizar los conocimientos adquiridos para definir contenidos, establecer dinámicas y planear evaluaciones para mejorar la enseñanza-aprendizaje.

Considero acertada la idea de que la búsqueda del saber demanda del maestro tener desarrolladas competencias personales, sociales y profesionales. Sin estas competencias se hace difícil comprometerse con la rigurosidad científica y mantener el espíritu crítico en el proceso de investigación.

En cuanto a los rasgos de la personalidad del maestro, estoy de acuerdo con la afirmación que hace el Lic. Wilfredo Rosario en el sentido de que la función de los docentes no consiste únicamente en transmitir contenidos, sino que también deben ser capaces de motivar, seducir y orientar. Sin estos rasgos de la personalidad se alejan de su misión, convirtiéndose en seres apáticos, fiscalizadores, generando más estrés en sus estudiantes que aprendizaje. El dominio de un conjunto de competencias (conocimientos, destrezas, actitudes) facilita un ambiente de enseñanza abierto, dinámico y en confianza.

Me solidarizo con la idea de que el maestro eficaz es aquel que demuestra poseer flexibilidad, sensibilidad, capacidad, y además, sabe ser empático, objetivo, auténtico y sincero. El maestro ideal será aquel que interviene para que el alumno participe y aprenda; esté abierto al cambio y a la innovación; sea capaz de transmitir saberes de forma eficaz, positiva; y por supuesto, poseedor de una fuerte y profunda motivación intrínseca para realizar su trabajo de la mejor manera posible.

\section{Lic. Juan Féliz Alcántara Profesor Departamento de Humanidades Campus de Santiago \\ Comentario a la entrevista de la profesora Alexandra Borbón}

El título del artículo de nuestra querida profesora Alexandra Borbón cruza barreras más fuertes de las que posiblemente ella podría imaginar, ya que hace que nos identifiquemos con su sentir: "disfruto y comparto a plenitud mi labor académica".

La profesora Alexandra es un ser humano excepcional, inolvidable para muchos de sus estudiantes, pues con su paz y entrega les permite hacerse partícipes de esa enseñanza que con pasión y amor transmite en cada una de sus clases. Esto lo puedo decir con base y segura de lo que expreso, pues me siento privilegiada ya que fue mi profesora en la asignatura Ciencia de los Alimentos. Sus marcas son seguridad y precisión, además de ser una profesional increíble con grandes luces, cuyos aportes estarán con cada uno de nosotros, sus alumnos, para toda la vida.

Fue una gran sorpresa para mí, que, al iniciar como profesora en la PUCMM, me la encontré caminando en uno de los pasillos de esta mi alma mater y cómo de inmediato me saludó con cariño, llamándome por mi nombre y apellido e inmediatamente se puso a la orden para ayudarme.

La profesora Borbón entiende que cada estudiante es importante, y que además lo que transmite debe trascender, por lo que es necesario valorar y aplicar ese modelo de enseñanza. Felicito a mi maestra, por su dedicación, no solo a su labor docente, sino por todos sus aportes a la comunidad universitaria y su contribución al desarrollo de nuestra Universidad en el contexto educativo tanto a nivel nacional como internacional.

Lic. Ina Percival Directora de Administración Hotelera Campus Santo Tomás de Aquino 